\title{
Determinants of Student Mobility in Primary School in Rural Malawi: An Event History Analysis
}

\author{
Kyoko Taniguchi ${ }^{1, *}$ \\ ${ }^{1}$ Graduate school for International Development, Nagoya University, Furo-cho, Chikusa-ku, Japan \\ *Corresponding author: Graduate school for International Development, Nagoya University, Furo-cho, Chikusa-ku, \\ Japan. Tel: 81-90-1336-6992. E-mail: kyoko.taniguchi1909@gmail.com
}

Received: February 13, 2017

Accepted: February 21, 2017 Online Published: April 10, 2017

doi:10.5430/wje.v7n2p19

URL: https://doi.org/10.5430/wje.v7n2p19

\begin{abstract}
This study identifies individual, family, and school factors associated with student mobility. Specifically, for Grade 5 students, parents alive and school location were associated with transfer. For students in Grade 7, gender differences, levels of achievement, feelings about school, number of household tasks, distance to school, and parental habits of paying school fees were related to student mobility. Also, school location and mean number of grade repetitions for the institution are correlated with Grade 7 student mobility. The findings contribute to ongoing discussions about educational policy regarding transfer.
\end{abstract}

Keywords: student mobility; transfer; event history analysis; primary school; Malawi; Sub-Saharan Africa

\section{Introduction}

This study was initiated in response to the high transfer rates of primary school students in Malawi (Taniguchi, 2015a). According to data from academic year $2012 / 2013$ to $2013 / 2014$, more than $15 \%$ of Malawian students transferred schools. This finding raises three questions: Why do so many students transfer to another school? What are the characteristics of students most likely to transfer to another school? From which types of schools are children likely to transfer?

Less attention has been paid to transfer or student mobility in developing countries than in developed countries (Taniguchi, 2015b). In fact, transfer rate has not been calculated for most countries (Ibid). Even international organizations such as the United Nations Educational, Scientific and Cultural Organization (UNESCO) and The World Bank do not research these data. Three reasons explain the lack of interest in transfer rates. First, over recent decades, developing societies have sought to expand school access such that students either did not change schools or stakeholders have not regarded student mobility as a major problem. However, as access to primary education has improved in most developing countries, families are starting to choose particular schools in some areas. Second, many researchers have focused on grade repetition and school dropout because these events directly affect noncompletion of primary school. Finally, although student mobility or transfer has increased at the secondary-school level in developed countries (Kerbow, 1996, Rumberger et al., 1999; Rumberger \& Palardy, 2005), researchers have not generally considered the phenomenon at the primary-school level.

Despite the lack of recent attention, the question is raised: Does student mobility or transfer exert a harmful influence on completion of primary school in developing countries? Few studies offer analysis on the causes of student mobility or transfer in developing countries, so the answer remains unclear. However, research suggests that in developed countries student mobility or transfer has a negative impact on schooling (Kerbow, 1996).

The objective of this study is to identify the causes of transfer in primary schools in rural Malawi. To pursue this aim, three research questions are answered: (1) Is transfer a student or school matter? (2) What individual and family factors influence the choice to transfer? (3) What classroom and school factors influence the incidences of transfer?

The structure of this paper is as follows: Section 2 offers a review of the literature on student mobility and transfer. Section 3 describes the study methodology. The findings are presented in Section 4. The discussion is outlined in Section 5, and the final section offers a conclusion to summarize findings and suggest future research. 


\section{Literature Review}

Most research on student mobility or transfer has been conducted in the United States and the United Kingdom. In the United States, change of family residence was not the only cause of transfer (Kerbow, 1996). For example, more students with poor academic achievement change schools than do those who demonstrate academic success (Mao et al., 1997; Rumberger et al., 1999; Wright, 1999; Engec, 2006; South et al., 2007). Students with demonstrated behavioral problems in school are also among those found likely to transfer to another school (Nelson et al., 1996; Engec, 2006). Also, transfer students tend to come from single parent homes (Nelson et al., 1996).

Similar findings of the United States were obtained in the United Kingdom. As in the United States, change of residence was only one factor associated with transfer. Minority students (Dobson et al., 2000), those with low academic achievement (Strand \& Demie, 2007), and students from disadvantaged families (Tooley, 1997) were more likely to transfer schools.

Transfer or student mobility affects more than an individual or a family; it also affects schools. Quality of schools has emerged as an important factor in transfer decisions (Kerbow, 1996; Rumberger et al., 1999). Moreover, Rumberger et al. (1999) found that schools often initiate student mobility. For social or academic reasons, schools can force students to transfer to another school. In addition, such transfer is associated with an increased risk of students dropping out of the education system (Rumberger et al., 1999; South et al., 2007).

Less attention has been paid to transfer or student mobility in developing countries than has been given to students in the United States and the United Kingdom. However, some students in sub-Saharan African countries have followed the trend of mobility. For example, researchers have found high rates of student mobility in Kenya (Nishimura \& Yamano, 2008), Uganda (Taniguchi, 2013), and Malawi (Taniguchi, 2015a). In Kenya, the number of students attending private primary schools increased from $4.8 \%$ in 2004 to $12.2 \%$ in 2007 (Nishimura \& Yamano, 2008). In Uganda, $67.8 \%$ and $55.5 \%$, respectively, of Grade 3 and 6 students transferred to other schools at least once; $39.0 \%$ and 34.7\% transferred more than twice (Taniguchi, 2013). In Malawi, $15.6 \%$ and $18.6 \%$, respectively, of Grade 5 and 7 students transferred within a single year (Taniguchi, 2015a).

Why do students transfer to another school? According to a study on school choice between public and private primary schools (Nishimura \& Yamano, 2008), students who earn a high score in the Kenya Certificate of Primary Education Examination were more likely to transfer to private schools than were low scorers. Also, children from relatively wealthy households were more likely to transfer to private schools than were those from poor households. Boys received more opportunities to transfer to private schools than did girls. According to one teacher's explanation in Uganda (personal communication), students transferred to another school because they wanted to avoid paying school fees or repeating grades. Similarly, in Malawi (personal communication), teachers explain the familial reasons as follows: family moves to accommodate a parent's employment situation; family experiences change or misfortune such as death of parents, poverty, or need to help another family; and family seeks a more advantaged environment with relatives, including living in a house nearer to a school, residing with the relative who serves as a teacher, or moving into relatively uncrowded quarters. Students also transfer due to specific school characteristics including lower fees and better conditions for learning.

Although the evidence remains sparse, students seem to transfer in sub-Saharan Africa for different reasons than do students from the United States and the United Kingdom. Because this assumption has not yet been properly investigated, more research must be undertaken to identify and compare the causes of transfer.

\section{Methodology}

\subsection{Sampling}

This study is based on the same sample described in Taniguchi (2015a). As mentioned the above, high transfer rates were discovered in the sample. An event history analysis was conducted to determine whether cohort students transfer to another school during a year. Unlike other methods, an event historical analysis allows for collection of data in which the effect of independent variables on dependent variables with a predetermined property is expressed at a specific time (Berry \& Berry, 1990).

Thirty of 178 public primary schools in the Nkhata Bay District of Malawi were selected based on clustering pass rates on the Primary School Leaving Certificate Examination (PSLCE) from 2010 to 2012. The field research was conducted from January to March 2013 and during the same months in 2014. In 2013, data were collected on 30 head teachers; 58 teachers; 1734 Grade 5 students; and 1353 Grade 7 students. In 2014, data on students who had been promoted to the next grade or instructed to repeat the same grade as well as those who dropped out of school or 
transferred to another school were retrieved. Due to missing data in both 2013 and 2014, information from 1449 Grade 5 students and 1294 Grade 7 students were analyzed.

The results are shown in Table 1. In an unexpected result, the transfer rates were relatively high: $15.6 \%$ for Grade 5 and $18.6 \%$ for Grade 7.

Table 1. Transition of Students from Academic Year 2012/2013 to 2013/2014

\begin{tabular}{llllllll}
\hline Grade & & Promotion & Repetition & Transfer & Dropout & Death & Total \\
\hline \multirow{2}{*}{5 to 6} & $N$ & 773 & 367 & 226 & 82 & 1 & 1449 \\
& $\%$ & 53.3 & 25.3 & 15.6 & 5.7 & 0.1 & 100.0 \\
\hline \multirow{2}{*}{7 to 8} & $N$ & 652 & 316 & 241 & 83 & 2 & 1294 \\
& $\%$ & 50.4 & 24.4 & 18.6 & 6.4 & 0.2 & 100.0 \\
\hline
\end{tabular}

Source: Developed by the author

In developed countries, transfer is classified into two types: with and without residence change (Kerbow, 1996). In most cases, families move because the parents change work place. In developing countries, the reason for residence change and resultant student transfer are numerous and include parent death or poverty (Taniguchi, 2015b). Therefore, the reasons for transfer cannot necessarily be ameliorated to discourage student transfer of schools in developing areas.

This study did not classify students who transferred into the two change of residence criteria for two reasons. First, the reasons for student transfer may not be fixable. Second, the high transfer rates were an unexpected result of the research; the item soliciting reasons for transfer was not included in the questionnaire for students. Despite the lack of data and the difficulty in rectifying negative situations associated with transfer, this study seeks to suggest some causes of transfer for the students in the sample.

\subsection{Instruments}

Two types of research instruments were used: English and mathematics tests as well as questionnaires. The original student tests were created from curricula, textbooks, zonal and national examinations, and previous studies that showed results of the Monitoring Achievement in Lower Primary and SACMEQ III assessments. This study measured basic reading skills from Level 1 (prereading) to Level 4 (reading for meaning) and basic numeracy skills from Level 1 (prenumeracy) to Level 4 (beginning numeracy) as defined by SACMEQ III. This choice was prompted by SACMEQ III reports that $26.7 \%$ and $8.3 \%$ of Grade 6 students in Malawi have surpassed basic reading and numeracy skills, respectively (Hungi et al., 2010). Also, determining the basic skills that must improve for increased academic achievement is important information to garner. The English and math tests for Grade 5 each consisted of 35 questions, and the corresponding tests for Grade 7 each featured 40 questions. Before the tests were administered in the 30 schools, a pretest was conducted in one school. After checking the results as well as getting feedback from school teachers and primary-level education advisers in the district office, tests were modified. In 2013, revised tests were first distributed to students in the 30 Malawian schools chosen for study. The questionnaire for students was translated into the local language, Chichewa, and back translation was carried out to check for mistakes.

Three types of questionnaires (for students, head teachers, and classroom teachers) were developed with respect to the literature on grade repetition in developing countries (El-Hassan, 1988; Gomes-Neto \& Hanushek, 1994; Liddell \& Rae, 2001; Marshall, 2003; Fleish \& Shindler, 2009). In addition, the questionnaires from a SACMEQ study were used as follow-up instruments to add information unavailable from the limited measured variables based on few student mobility studies conducted in developing countries.

\subsection{Analyses}

The results of this study relied on a two-level logistic regression. Several steps were conducted before the two-level logistic regression was employed. First, binary data for transfer were garnered to create the dependent variable. Second, the independent variables were constructed (see Appendixes A, B, and C). Then, correlations between the independent variables were examined. The individual-level variables were characterized by random missing data points, and to substitute for the missing information, multiple imputations were conducted with the available data. The obtained data were fully and effectively analyzed because the final data set provided sufficient information (Enders, 2010). 
To determine student achievement levels, test scores were turned into ability scores through item response theory (IRT). In IRT, student ability is typically found to range from -3.00 to 3.00 , with 0.00 representing average ability level. As meaning is difficult to attribute to negative ability scores, the scores in this study were transformed so the mean was 500 and the standard deviation was 100 .

For the analyses, a null mode, also called an emptv model. was created to calculate the proportion of between variance to overall variance using the formula $\tau_{00} /\left(\tau_{00}+\pi^{2} / 3\right)$, in a method known as intra-class correlation. Then, three models, Model 1 for the student level, Model 2 for the school level, and Model 3 for full model (the student and school levels) were created to analyze factors possibly related to transfer. The formula of two-level logistic regression was as follows:

Level 1: $\operatorname{logit}\left(P_{i j}\right)=\ln \left(P_{i j} / 1-P_{i j}\right)=\beta_{0 j}+\beta_{k j} x_{k j}$

Level 2: $\beta_{0 j}=\gamma_{00}+\gamma_{0 p} w_{p j}+\mu_{0 j}$, where $\mu_{0 j} \sim N\left(0, \tau_{00}\right)$

$$
\beta_{k j}=\gamma_{k 0}
$$

Mixed: $\operatorname{logit}\left(P_{i j}\right)=\gamma_{00}+\gamma_{0 p} w_{p j}+\gamma_{k 0} x_{i j}+\mu_{0 j}$, where

$P_{i j}$ is the probability of transfer (dependent variable)

$\beta_{0 j}$ is the intercept for school $j$

$\beta_{k j}$ is the slope

$x_{k j}$ is an explanatory variable for Level 1 (independent variable)

$\gamma_{00}$ is mean transfer for school

$\gamma_{0 p}$ is mean transfer difference between schools

$w_{p j}$ is an explanatory variable at Level 2 (independent variable) explaining the intercept

$\mu_{0 j}$ represents random variables with 0 means and variances

$\gamma_{k 0}$ is the average value of the explanatory variable (independent variable) for the repetition slope by school

\section{Findings}

\subsection{Transfer is a Student and School Matter}

Tables 2 and 3 show the results of analyses for students in Grades 5 and 7. The values of intra-class correlation for Grade 5 and 7 models were 0.078 and 0.091 , respectively, which means that $7.8 \%$ and $9.1 \%$ of the factors associated with transfer in Grades 5 and 7, respectively, were explained by school-level factors. This finding also means that the majority of factors related to transfer were explained by student-level effects. 
Table 2. Model for Grade 5

\begin{tabular}{|c|c|c|c|c|c|c|c|c|c|c|c|c|}
\hline \multirow[t]{3}{*}{ Variable } & \multicolumn{3}{|l|}{ Null } & \multicolumn{3}{|l|}{ Model 1} & \multicolumn{3}{|l|}{ Model 2} & \multicolumn{3}{|l|}{ Model 3} \\
\hline & & & & \multicolumn{3}{|l|}{ Student } & \multicolumn{3}{|l|}{ School } & \multicolumn{3}{|l|}{ Full } \\
\hline & $E S$ & $S E$ & $O R$ & $E S$ & $S E$ & $O R$ & $E S$ & $S E$ & $O R$ & $E S$ & $S E$ & OR \\
\hline \multicolumn{13}{|l|}{ Student-level } \\
\hline \multicolumn{13}{|l|}{ Individual } \\
\hline Achievement & & & & 0.000 & 0.001 & 1.000 & & & & 0.000 & 0.001 & 1.000 \\
\hline Student gender & & & & -0.218 & 0.150 & 0.804 & & & & -0.222 & 0.151 & 0.801 \\
\hline Age of first entry & & & & -0.055 & 0.065 & 0.946 & & & & -0.055 & 0.066 & 0.946 \\
\hline Preschool attendance & & & & 0.119 & 0.097 & 1.126 & & & & 0.109 & 0.100 & 1.115 \\
\hline Days absent during the previous 2 weeks & & & & 0.017 & 0.051 & 1.017 & & & & 0.023 & 0.049 & 1.023 \\
\hline Number of grade repetitions & & & & 0.040 & 0.090 & 1.041 & & & & 0.045 & 0.088 & 1.046 \\
\hline Repetition at Grade 5 or 7 & & & & -0.041 & 0.197 & 0.960 & & & & -0.050 & 0.195 & 0.951 \\
\hline Homework & & & & -0.033 & 0.093 & 0.968 & & & & -0.059 & 0.095 & 0.943 \\
\hline Taking extra classes & & & & 0.230 & 0.183 & 1.259 & & & & 0.272 & 0.187 & 1.313 \\
\hline Health condition & & & & 0.085 & 0.069 & 1.089 & & & & 0.082 & 0.068 & 1.085 \\
\hline Self-esteem & & & & 0.015 & 0.046 & 1.015 & & & & 0.014 & 0.045 & 1.014 \\
\hline Feelings about school & & & & 0.029 & 0.039 & 1.029 & & & & 0.040 & 0.039 & 1.041 \\
\hline Educational aspiration & & & & -0.031 & 0.084 & 0.969 & & & & -0.025 & 0.083 & 0.975 \\
\hline \multicolumn{13}{|l|}{ Family } \\
\hline Number of siblings & & & & -0.064 & 0.045 & 0.938 & & & & -0.058 & 0.045 & 0.944 \\
\hline Speaking language of instruction & & & & 0.046 & 0.080 & 1.047 & & & & 0.054 & 0.078 & 1.055 \\
\hline Parents alive & & & & $-0.303^{* * *}$ & 0.092 & 0.739 & & & & $-0.302 * * *$ & 0.088 & 0.739 \\
\hline Living with parents or relatives & & & & 0.121 & 0.120 & 1.129 & & & & 0.109 & 0.119 & 1.115 \\
\hline Socioeconomic status & & & & 0.006 & 0.018 & 1.006 & & & & 0.004 & 0.019 & 1.004 \\
\hline Number of books at home & & & & -0.147 & 0.080 & 0.863 & & & & -0.142 & 0.084 & 0.868 \\
\hline Distance to school & & & & 0.094 & 0.109 & 1.099 & & & & 0.064 & 0.107 & 1.066 \\
\hline Household tasks & & & & -0.008 & 0.008 & 0.992 & & & & -0.009 & 0.008 & 0.991 \\
\hline Meals per week & & & & 0.004 & 0.034 & 1.004 & & & & 0.009 & 0.033 & 1.009 \\
\hline Homework help at home & & & & -0.097 & 0.091 & 0.908 & & & & -0.129 & 0.096 & 0.879 \\
\hline Paying fees & & & & -0.037 & 0.041 & 0.964 & & & & -0.032 & 0.039 & 0.969 \\
\hline Parental support & & & & 0.057 & 0.040 & 1.059 & & & & 0.060 & 0.039 & 1.062 \\
\hline \multicolumn{13}{|l|}{ School level } \\
\hline Mean achievement & & & & & & & 0.000 & 0.001 & 1.000 & 0.000 & 0.001 & 1.000 \\
\hline Mean socioeconomic status & & & & & & & 0.001 & 0.070 & 1.001 & -0.024 & 0.077 & 0.976 \\
\hline Mean number of grade repetitions & & & & & & & -0.315 & 0.546 & 0.730 & -0.988 & 0.560 & 0.372 \\
\hline Class size & & & & & & & 0.001 & 0.003 & 1.001 & 0.001 & 0.003 & 1.001 \\
\hline School location & & & & & & & $0.847^{* * *}$ & 0.266 & 2.333 & $0.941 * * *$ & 0.245 & 2.563 \\
\hline School facilities & & & & & & & 0.108 & 0.077 & 1.114 & 0.098 & 0.077 & 1.103 \\
\hline \multicolumn{13}{|l|}{ Between level } \\
\hline Intercept & $1.768 * * *$ & 0.161 & & $1.835^{* * *}$ & 0.160 & & $1.691^{* * *}$ & 0.120 & & $1.754 * * *$ & 0.113 & \\
\hline Variance & $0.278 * *$ & 0.146 & & $0.301 * * *$ & 0.153 & & 0.079 & 0.101 & & 0.051 & 0.097 & \\
\hline ICC & 0.078 & & & 0.084 & & & 0.023 & & & 0.015 & & \\
\hline Log-likelihood & -603.579 & & & -585.593 & & & -597.216 & & & -578.361 & & \\
\hline AIC & 1211.158 & & & 1225.186 & & & 1210.433 & & & 1222.722 & & \\
\hline $\mathrm{BIC}$ & 1221.598 & & & 1366.116 & & & 1252.190 & & & 1394.970 & & \\
\hline
\end{tabular}

Source: Developed by the author from research data. 
Table 3. Model for Grade 7

\begin{tabular}{|c|c|c|c|c|c|c|c|c|c|c|c|c|}
\hline \multirow[t]{3}{*}{ Variable } & \multicolumn{3}{|l|}{ Null } & \multicolumn{3}{|l|}{ Model 1} & \multicolumn{3}{|l|}{ Model 2} & \multicolumn{3}{|l|}{ Model 3} \\
\hline & \multirow[b]{2}{*}{$E S$} & \multirow[b]{2}{*}{$S E$} & \multirow[b]{2}{*}{$O R$} & \multicolumn{3}{|l|}{ Student } & \multicolumn{3}{|l|}{ School } & \multicolumn{3}{|l|}{ Full } \\
\hline & & & & $E S$ & $S E$ & $O R$ & $E S$ & $S E$ & $O R$ & $E S$ & $S E$ & $O R$ \\
\hline \multicolumn{13}{|l|}{ Fixed Effect } \\
\hline \multicolumn{13}{|l|}{ Student level } \\
\hline \multicolumn{13}{|l|}{ Individual } \\
\hline Achievement & & & & $-0.001 *$ & 0.001 & 0.999 & & & & $-0.002 *$ & 0.001 & 0.998 \\
\hline Student gender & & & & $-0.505^{* * *}$ & 0.157 & 0.604 & & & & $-0.499 * *$ & 0.163 & 0.607 \\
\hline Age of first entry & & & & 0.074 & 0.048 & 1.077 & & & & 0.076 & 0.047 & 1.079 \\
\hline Preschool attendance & & & & -0.163 & 0.094 & 0.850 & & & & -0.163 & 0.094 & 0.850 \\
\hline Days absent during the previous 2 weeks & & & & -0.024 & 0.073 & 0.976 & & & & -0.026 & 0.072 & 0.974 \\
\hline Number of grade repetitions & & & & 0.153 & 0.088 & 1.165 & & & & 0.126 & 0.085 & 1.134 \\
\hline Repetition at Grade 5 or 7 & & & & -0.188 & 0.190 & 0.829 & & & & -0.208 & 0.189 & 0.812 \\
\hline Homework & & & & 0.158 & 0.105 & 1.171 & & & & 0.136 & 0.109 & 1.146 \\
\hline Taking extra classes & & & & 0.094 & 0.143 & 1.099 & & & & 0.101 & 0.139 & 1.106 \\
\hline Health condition & & & & 0.040 & 0.079 & 1.041 & & & & 0.026 & 0.081 & 1.026 \\
\hline Self-esteem & & & & -0.023 & 0.051 & 0.977 & & & & -0.026 & 0.053 & 0.974 \\
\hline Feelings about school & & & & $-0.127^{*}$ & 0.053 & 0.881 & & & & $-0.114^{*}$ & 0.056 & 0.892 \\
\hline Educational aspiration & & & & -0.047 & 0.198 & 0.954 & & & & -0.056 & 0.194 & 0.946 \\
\hline \multicolumn{13}{|l|}{ Family } \\
\hline Number of siblings & & & & -0.074 & 0.053 & 0.929 & & & & -0.075 & 0.053 & 0.928 \\
\hline Speaking language of instruction & & & & -0.001 & 0.084 & 0.999 & & & & -0.006 & 0.085 & 0.994 \\
\hline Parents alive & & & & 0.035 & 0.115 & 1.036 & & & & 0.031 & 0.117 & 1.031 \\
\hline Living with parents or relatives & & & & -0.011 & 0.098 & 0.989 & & & & -0.008 & 0.098 & 0.992 \\
\hline Socioeconomic status & & & & -0.001 & 0.025 & 0.999 & & & & -0.003 & 0.026 & 0.997 \\
\hline Number of books at home & & & & 0.022 & 0.073 & 1.022 & & & & 0.030 & 0.072 & 1.030 \\
\hline Distance to school & & & & $0.197 *$ & 0.088 & 1.218 & & & & $0.204 *$ & 0.091 & 1.226 \\
\hline Household tasks & & & & $-0.058 * * *$ & 0.014 & 0.944 & & & & $-0.056^{* *}$ & 0.014 & 0.946 \\
\hline Meals per week & & & & 0.036 & 0.028 & 1.037 & & & & 0.034 & 0.028 & 1.035 \\
\hline Homework help at home & & & & $-0.221^{*}$ & 0.111 & 0.802 & & & & -0.212 & 0.111 & 0.809 \\
\hline Paying fees & & & & $0.083^{*}$ & 0.035 & 1.087 & & & & $0.078^{*}$ & 0.036 & 1.081 \\
\hline Parental support & & & & -0.007 & 0.033 & 0.993 & & & & -0.005 & 0.032 & 0.995 \\
\hline \multicolumn{13}{|l|}{ School level } \\
\hline Mean achievement & & & & & & & 0.000 & 0.002 & 1.000 & 0.003 & 0.002 & 1.003 \\
\hline Mean socioeconomic status & & & & & & & -0.007 & 0.083 & 0.993 & -0.058 & 0.096 & 0.944 \\
\hline Mean number of grade repetitions & & & & & & & $1.276^{*}$ & 0.596 & 3.582 & $1.379^{*}$ & 0.692 & 3.971 \\
\hline Class size & & & & & & & 0.001 & 0.003 & 1.001 & 0.000 & 0.003 & 1.000 \\
\hline School location & & & & & & & $0.709^{* *}$ & 0.240 & 2.032 & $0.638^{*}$ & 0.276 & 1.893 \\
\hline School facilities & & & & & & & -0.041 & 0.093 & 0.960 & -0.046 & 0.113 & 0.955 \\
\hline \multicolumn{13}{|l|}{ Between level } \\
\hline Intercept & $1.494 * * *$ & 0.143 & & $1.586^{* * *}$ & & & $1.480 * * *$ & 0.111 & & $1.579 * * *$ & 0.126 & \\
\hline Variance & $0.331^{*}$ & 0.154 & & $0.375^{*}$ & 0.169 & & 0.146 & 0.102 & & 0.183 & 0.127 & \\
\hline $\mathrm{ICC}$ & 0.091 & & & 0.102 & & & 0.042 & & & 0.053 & & \\
\hline Log-likelihood & -592.042 & & & -562.741 & & & -585.989 & & & -557.972 & & \\
\hline AIC & 1188.084 & & & 1179.481 & & & 1187.978 & & & 1181.944 & & \\
\hline $\mathrm{BIC}$ & 1198.279 & & & 1317.115 & & & 1228.759 & & & 1350.163 & & \\
\hline
\end{tabular}

$* * * p<.001 ; * * p<.01 ; * p<.05$.

Source: Developed by the author from research data.

4.2 Individual and Family Factors Affecting Transfer

4.2.1 Individual and Family Factors in Grade 5

Model 1 in Table 2 shows the results of individual and family factors affecting student transfer in Grade 5. The 
variable, parents alive, was negative and significant at the 0.001 level, which means that students with no parents were more likely to transfer to another school than those with parents $(O R=0.739, p<.001)$. Students with no parents had an increased possibility of transfer (0.739). Based on this model, if the transfer rate of students with no parents were $10.00 \%$, then the transfer rate of students with one parent would be $2.61 \%$ [ $10.00 \% *(1-0.739)]$. Even when school-level factors were controlled, as in Model 3 which shows school-level factors as added to Model 1, the value of transfer for parents alive was significant at the 0.001 level.

\subsubsection{Individual and Family Factors in Grade 7}

Model 1 in Table 3 shows the results of individual and family factors affecting transfer in Grade 7. At the individual level, student gender was the strongest factor related to transfer. It was negative and significant at the 0.001 level, which means that girls were more likely to transfer to another school than were boys $(O R=0.604, p<.001)$ Based on this model, if the transfer rate of girls were $10.00 \%$, the transfer rate of boys would be $3.96 \%$ [ $10.00 \% *(1-$ $0.604)]$.

Like student gender, achievement and feelings about school were associated with significant and relatively high odds of transfer for students in Grade 7. Students with low achievement were more likely to transfer to another school than those with higher achievement $(O R=0.999, p<.05)$. Based on this model, if the transfer rate of students with low achievement were $10.00 \%$, the transfer rate of students with high achievement would be $0.01 \%[10.00 \% *(1-$ 0.999)].

Grade 7 students with a negative feeling about school were more likely to transfer to another school than those who reported a positive feeling about school $(O R=0.881, p<.05)$. Based on this model, if the transfer rate of students with a negative feeling about school were $10.00 \%$, the transfer rate of students with a positive feeling about school would be $1.19 \%$ [10.00\%*(1-0.881)]. By controlling school-level factors (Model 3), the significance of student gender decreased to the 0.01 level, but remains stronger than the other two significant factors. The significance values associated with the variables of achievement and feelings about school were the same in Models 1 and 3.

At the family level, four factors were significant at the 0.05 level in Model 1 for Grade 7 students. However, when school-level factors (Model 3) were controlled, the data show that homework help at home was not significant. Household tasks showed significance among family-level data related to transfer, meaning that students with few household tasks were more likely to transfer to another school than those with many tasks $(O R=0.944, p<.001)$. Based on this model, if the transfer rate of students with a score of 10 for household tasks were $10.00 \%$, the transfer rate of students with a score of 11 would be $0.56 \%$ [10.00\%*(1-0.944)].

At the 0.05 level, distance to school and paying fees were also significant variables associated with Grade 7 student transfer. Students living at greater distance from school were more likely to transfer to another school than those living close to the school $(O R=1.218, p<.05)$. Based on this model, if the transfer rate of students living at a distance of $0-0.5 \mathrm{~km}$ were $10.00 \%$, the transfer rate of students at a distance of $0.6-1.0 \mathrm{~km}$ would be $12.18 \%$ $(10.00 \% * 1.218)$. Families who paid student fees on time were more likely to transfer to another school than those who did not $(O R=1.087, p<.05)$. Based on this model, if the transfer rate of students with a score of 10 for paying fees were $10.00 \%$, the transfer rate of students with a score of 11 would be $10.87 \%(10.00 \% * 1.087)$.

\subsection{School Factors Affecting Transfer}

Although the percentage of school factors to overall factors was relatively small for both students in Grades 5 and 7 , the school factors that potentially influence transfer deserve attention. Model 2, as shown in Tables 2 and 3, give the results for students in Grades 5 and 7, respectively. Model 3, as shown in Tables 2 and 3, provide the results for students in Grades 5 and 7 after individual and family factors have been controlled. Because the majority of factors could be explained by individual factors, Model 3 provides the most useful information.

According to Model 3 for Grade 5 shown in Table 2, school location was significant and indicated that students in schools located in semi-urban areas were more likely to transfer to another school than those in rural schools $(O R=$ $2.563, p<.001)$. Based on the model, if the transfer rate of students in rural schools were $10.00 \%$, that of students in semi-urban schools would be $25.63 \%(10.00 \% * 2.563)$.

According to Table 3, the mean number of grade repetitions in the school and school location for Grade 7 students were significant and indicated a high probability of transfer. Students in schools with a high mean number of grade repetitions were more likely to transfer to another school than those in schools with a low mean number of grade repetitions $(O R=3.971, p<.05)$. Based on this model, if the transfer rate of students in schools with a mean number of grade repetitions of 1.0 were $10.00 \%$, the transfer rate in schools with a mean number of grade repetitions of 2.0 would be $39.71 \%(10.00 \% * 3.971)$. Like the Grade 5 students (Table 2) students in Grade 7 in semi-urban areas were 
more likely to transfer schools than were those in rural schools $(O R=1.893, p<.05)$. Based on this model, if the transfer rate of Grade 7 students in rural schools were $10.00 \%$, that of Grade 7 students in semi-urban schools would be $18.93 \%(10.00 \% * 1.893)$.

\section{Discussion}

\subsection{Is Transfer a Student Matter in Rural Malawi?}

The data show that the proportion of school-level variance to the overall variance was small, $0.078(7.8 \%)$ for Grade 5 students and $0.091(9.1 \%)$ for Grade 7 students. These results indicate that most transfers were the result of individual- and family-level factors. In all of the sampled schools, similar characteristics were associated with students likely to transfer to another school.

Yet, 24 of the 30 studied schools were located in rural areas where students do not have as many options for education as do students in urban areas. As a result, schools in this study might not exert as much influence on transfer rates as individual- and family-level factors. Further studies with more samples, especially including urban schools, need to be conducted. Also, the schools need to be further classified into urban and semi-urban categories to compute the proportion of school influence overall.

\subsection{Who is Most Likely to Transfer to Another School?}

Factors affecting transfer were different for Grades 5 and 7. Therefore, the causes of transfer may differ between the lower and upper grades in general.

At the lower grade, the main reason for transfer was a surviving parent. In a previous study, Nelson et al. (1996) found that students with single parent are more likely to change schools. In rural area of Malawi, orphaned children are raised by relatives, and children moving into a new home may also be transferring to a new school. In these situations, no action can be taken to avoid transfer.

However, the data in this study show a different scenario for students in Grade 7 than for those in Grade 5. In Grade 7, girls were more likely to transfer to another school than boys. This finding may be explained by early marriage and pregnancy; however, no information was gathered specifically about the transferring girls in this study. In another related explanation, parents may send the older girls to better schools as a means of avoiding early marriage and pregnancy. Further research should examine the reasons Grade 7 girls transfer.

Second, children with fewer household tasks were more likely to transfer to another school than did children who reportedly completed many household chores. Advantaged parents desire and send their children to go to better quality of school, while disadvantaged parents cannot do so. They employ with their children to help sustain the family. This finding is inconsistent with the work of Tooley (1997), who found that students from disadvantaged families were more likely to transfer to another school.

Third, children with low academic achievement were more likely to transfer to another school than were their high-achieving peers. This finding comports with those of Strand and Demie (2007). The decision to change schools may reflect a desire for a school with a better reputation or a wish to find a school in which the student may have peers at similar performance levels.

Fourth, children with negative feelings transferred at higher rates than those who reported having positive feelings about school. However, children who have low achievement and negative feelings about school seem to repeat grades or drop out, and other research suggests that those unwilling to transfer are at increased risk of attrition (Rumberger et al., 1999; South et al., 2007).

Fifth, children who live relatively a long distance from the school were more likely to transfer to another school than were those who live close to a school. If relatives live near a school, parents may send their children to stay with the relatives.

Finally, families willing to pay fees were more likely to transfer their students to another school than were those who did not pay fees. This was an unexpected result. Parents who regularly paid fees might have high expectations for schooling, and if the school does not meet those expectations, dissatisfied parents may send their children to another school.

When the results of this study are compared to previous studies conducted in sub-Saharan Africa, differences appear to emerge. Through a study on school choice between public and private schools, Nishimura and Yamano (2008) found that boys, high-achieving students, and children from advantaged families were more likely to transfer to 
private schools. They analyzed characteristics of students who transferred from a low quality school to a higher quality school. The data in the current study do not identify the status or quality of schools to which students transferred. A follow-up study on transferred-in students might provide information on reasons for transferring schools and ascertaining school quality.

\subsection{Which Schools Experience the Greater Number of Transfers?}

School location was strongly related to student transfer. Students in semi-urban schools were more likely to transfer to another school than were those in rural schools. Two potential reasons explain this finding. First, in semi-urban areas, more than one school is usually located within walking distance, and so students can readily change from one school to another; in rural areas, the schools are farther apart and so students may not be able to walk to an alternative facility. Second, parents living in semi-urban areas may have jobs with steady incomes; they have more opportunities than their rural counterparts to be employed in government offices, schools, or hospitals. Therefore, comparison of the transfer rates between semi-urban and rural schools is inappropriate and school location should be determined in other studies of factors that influence transfer rates. Research on larger sample sizes than used in this study will allow for school categorization based on location.

Another factor, a large number of grade repetitions, was associated with increased transfer rates for students in Grade 7. This pattern may be related to the national examination in Malawi in which nonpassing students - especially those in higher grade levels - must repeat the grade. Students needing to repeatedly reenroll in the same grade may seek to change to another school in hope of obtaining better preparation for the exam. Additional research needs to done to analyze the relationship between grade repetitions and scores on the national examination.

\section{Conclusion}

This study aims to find patterns of and suggest the causes of transfer in primary schools in rural Malawi. The findings contribute preliminary information for reducing unnecessary transfer in primary education.

Grade 5 students without parents were at increased risk of transfer to another school. Grade 7 girls were more likely to transfer to another school than were boys in the same grade. Students who demonstrated low achievement and who reported negative feelings about school, responsibility for completing many household tasks, travel some distance to school, and parents who paid school fees all were at higher risk of transfer.

In addition to individual and family factors, this study identified school factors that may contribute to transfer. Students in semi-urban schools were more likely to transfer to another school than were their rural counterparts. Grade 7 students in schools with a high mean number of grade repetitions were more likely to transfer to another school than those in schools with a low mean number of grade repetitions.

In addition to difficulty in identifying the causes of transfer, two other limitations characterize this study. First, the research was conducted with relatively few schools in one rural district. A sample that included urban districts may yield different results. Therefore, the findings cannot be extended to the whole country of Malawi. In particular, school factors need to be studied in a larger sample. Second, the research accounted for transfer over one year. Looking at data from multiple years would yield deeper understanding of transfer patters and may offer insight into the causes of transfer.

Despite these few limitations, this study offers analysis on student, family, and school factors related to transfer in a rural area of Malawi. The results of this study imply that the necessity of student mobility or transfer in rural Malawi seems to be mixed. Those who choose to transfer seem to be at increased risk for grade repetition and dropout, which is associated with negative outcomes, including noncompletion of primary school. However, the relationships between transfer, grade repetition, and dropout have not been clearly established. Researchers need to analyze these relationships and extend their studies to other districts in Malawi and other sub-Saharan African countries.

\section{Acknowledgements}

I am grateful for the financial support from the Sasakawa Scientific Research Grant extended for this study from the Japan Science Society, Hiroshima University Alumni Association, and Japan Society for the Promotion of Science. I also thank officers in the Nkhata Bay District and teachers and students in Malawi who cooperated with the completion of this research. 


\section{References}

Berry, F. S., \& Berry, W. D. (1990). State lottery adoptions as policy innovations: an event history analysis. The American Political Science Review, 84(2), 395-415. https://doi.org/10.2307/1963526

Dobson, J. M., Henthorne, K., \& Lynas, Z. (2000). Pupil mobility in schools: Final report. Migration Research Unit.

El-Hassan, K. (1998). Relation of academic history and demographic variables to grade retention in Lebanon. The Journal of Educational Research, 91(5), 279-289. https://doi.org/10.1080/00220679809597555

Enders, C. K. (2010). Applied Missing Data Analysis. The Guildford Press.

Engec, N. (2006). Relationship between mobility and student performance and behavior. Journal of Educational Research, 99(3), 167-178. https://doi.org/10.3200/JOER.99.3.167-178

Fleish, B., \& Shindler, J. (2009). Gender repetition: school access, transitions and equity in the 'birth-to-twenty' cohort panel study in urban South Africa. Comparative Education, 45(2), 265-279. https://doi.org/10.3200/JOER.99.3.167-178

Gomes-Neto, J. B., \& Hanushek, E. A. (1994). Causes and consequences of grade repetition: evidence from Brazil. Economic Development and Cultural Change, 43(1), 117-148. https://doi.org/10.1086/452138

Hungi, N., Makuwa, D., Ross, K., Saito, M., Dolata, S., \& Cappelle, F. V. et al. (2010). SACMEQIII Project Result: Pupil achievement levels in reading and mathematics. Working Document Number 1. Paris: SACMEQ.

Kerbow, D. (1996). Patterns of urban student mobility and local school reform (No. 5). Chicago, IL: University of Chicago.

Liddell, C., \& Rae, G. (2001). Predicting early grade retention: a longitudinal investigation of primary school progress in a sample of rural South African children. British Journal of Educational Psychology, 71(3), 413-428. https://doi.org/10.1348/000709901158596

Malawi Ministry of Education Science and Technology (MoEST). (2011). Educational Management Information System (EMIS). Educational Statistics 2010. Lilongwe, Malawi: Author.

Malawi Ministry of Education Science and Technology (MoEST). (2012). Educational Management Information System (EMIS). Educational Statistics 2011. Lilongwe, Malawi: Author.

Malawi Ministry of Education Science and Technology (MoEST). (2013). Educational Management Information System (EMIS). Educational Statistics 2012. Lilongwe, Malawi: Author.

Mao, M. X., Whitsett, M. D., \& Mellor, L. T. (1997). Student mobility, academic performance, and school accountability. Paper presented at the annual meeting of the American Educational Research Association, Chicago, IL.

Marshall, J. H. (2003). Grade repetition in Honduran primary schools. International Journal of Educational Development, 23, 591-605. https://doi.org/10.1016/S0738-0593(03)00060-9

Nelson, P. S., Simoni, J. M., \& Adelman, H. S. (1996). Mobility and school functioning in the early grades. Journal of Educational Research, 89(6), 365-369. https://doi.org/10.1080/00220671.1996.9941340

Nishimura, M., \& Yamano, T. (2008). School choice between public and private primary schools under the free primary education policy in rural Kenya. GRIPS Discussion Paper, 08-02. Tokyo, Japan: Graduate Institute for Policy Studies.

Rumberger, R. W., Larson, K. A., Ream, R. K., \& Palardy, G. J. (1999). The educational consequences of mobility for California students and schools. Research Series 99-2. Santa Barbara: University of California, Santa Barbara.

Rumberger, R. W., \& Palardy, G. J. (2005). Test scores, dropout rates, and transfer rates as alternative indicators of high school performance. American Educational Research Journal, 42(1), 3-42. https://doi.org/10.3102/00028312042001003

South, S. J., Haynie, D. L., \& Bose, S. (2007). Student mobility and school dropout. Social Science Research, 26, 68-94. https://doi.org/10.1016/j.ssresearch.2005.10.001

Strand, S., \& Demie, F. (2007). Pupil mobility, attainment and progress in secondary school. Educational Studies, 33(3), 313-331. https://doi.org/10.1080/03055690701423184

Taniguchi, K. (2013). Analysis of effective school indicators: a case of primary schools in the Mpigi district in 
Uganda. Paper presented the Africa Education Research Forum, Kyoto Women's University, Kyoto, Japan.

Taniguchi, K. (2015a). Determinants of grade repetition in primary school in sub-Saharan Africa: an event history analysis for rural Malawi. International Journal of Educational Development, 45, 98-111. https://doi.org/10.1016/j.ijedudev.2015.09.014

Taniguchi, K. (2015b). Multiple Indicators of School Effectiveness in Rural Malawi: A Multilevel Event History Analysis. Unpublished doctoral dissertation, Hiroshima University, Japan.

Tooley, J. (1997). On school choice and social class: a response to Ball, Bowe and Gewirtz. British Journal of Sociology of Education, 18(2), 217-230. https://doi.org/10.1080/0142569970180205

Wright, S. P., Horn, S. P., \& Sanders, W. (1997). Teacher and classroom context effects on student achievement: Implications for teacher evaluation. Journal of Personnel Evaluation in Education, 11, 57-97. https://doi.org/10.1023/A:1007999204543

Appendix A. Descriptive Statistics of Individual-Level Factors

\begin{tabular}{|c|c|c|c|c|c|}
\hline \multirow{2}{*}{ Variable name } & \multirow{2}{*}{ Scale } & \multicolumn{2}{|c|}{ Cohort 1} & \multicolumn{2}{|c|}{ Cohort 2} \\
\hline & & $M$ & $S D$ & $M$ & $S D$ \\
\hline Achievement & & 996.34 & 140.91 & 996.34 & 148.39 \\
\hline Student gender & $0=$ Girl; $1=$ Boy & 0.45 & 0.50 & 0.52 & 0.50 \\
\hline Age of first entry & & 5.85 & 1.56 & 5.83 & 1.57 \\
\hline Preschool attendance & $\begin{array}{l}0=\text { Never; } 0.5=\text { Two or three } \\
\text { months; } 1=\text { One year; } 2=\text { Two } \\
\text { years; } 3=\text { Three or more years }\end{array}$ & 0.70 & 0.82 & 0.76 & 0.86 \\
\hline Days absent during the previous 2 weeks & $\begin{array}{l}0=\text { Never; } 1=\text { Once; } 2=\text { Twice; } \\
3=\text { Three times; } 4=\text { Four or more } \\
\text { times }\end{array}$ & 1.30 & 1.31 & 1.01 & 1.15 \\
\hline Number of grade repetitions & $\begin{array}{l}0=0 ; 1=\text { Once } ; 2=\text { Twice } ; 3= \\
\text { Three or more than three }\end{array}$ & 0.99 & 0.91 & 0.90 & 0.79 \\
\hline Repetition at Grades 5 or 7 & $0=$ No; $1=$ Yes & 0.35 & 0.48 & 0.26 & 0.44 \\
\hline Homework & $\begin{array}{l}0=\text { Never; } 1=\text { Sometimes } ; 2= \\
\text { Most of time; } 3=\text { All of the time }\end{array}$ & 1.85 & 1.04 & 1.95 & 1.00 \\
\hline Taking extra classes & $0=\mathrm{No} ; 1=\mathrm{Yes}$ & 0.51 & 0.50 & 0.52 & 0.50 \\
\hline Health condition & $\begin{array}{l}1=\text { Very bad; } 2=\text { Bad; } 3= \\
\text { Normal; } 4=\text { Good; } 5=\text { Very good }\end{array}$ & 3.79 & 1.36 & 3.92 & 1.23 \\
\hline Self-esteem & $\begin{array}{l}\text { Sum of being able to do things as } \\
\text { well as the others can do }(1= \\
\text { Strongly disagree; } 2=\text { Disagree; } \\
3=\text { Agree; } 4=\text { Strongly agree }) \\
\text { and feeling like a useless person } \\
(4=\text { Strongly disagree; } 3= \\
\text { Disagree; } 2=\text { Agree; } 1=\text { Strongly } \\
\text { agree) }\end{array}$ & 4.49 & 1.71 & 5.61 & 1.38 \\
\hline Feelings about school & $\begin{array}{l}\text { Sum of liking to go to school, } \\
\text { enjoying learning at school, and } \\
\text { learning a lot school (Each } \\
\text { question: } 1=\text { Strongly disagree; } 2 \\
=\text { Disagree; } 3=\text { Agree; } 4= \\
\text { Strongly agree) }\end{array}$ & 10.42 & 2.25 & 8.13 & 1.45 \\
\hline Educational aspiration & $\begin{array}{l}1=\text { Primary school; } 2=\text { Junior } \\
\text { secondary school; } 3=\text { Senior } \\
\text { secondary school; and } 4=\text { More } \\
\text { than secondary school }\end{array}$ & 3.04 & 1.16 & 3.76 & 0.56 \\
\hline
\end{tabular}


Appendix B. Descriptive Statistics of Family-Level Factors

\begin{tabular}{|c|c|c|c|c|c|}
\hline \multirow{2}{*}{ Variable name } & \multirow{2}{*}{ Scale } & \multicolumn{2}{|c|}{ Cohort 1} & \multicolumn{2}{|c|}{ Cohort 2} \\
\hline & & $M$ & $S D$ & $M$ & $S D$ \\
\hline Number of siblings & $0=0 ; 1=1 ; 2=2 ; 3=3 ; 4=4 ; 5=5$ or more & 2.44 & 1.56 & 2.21 & 1.45 \\
\hline Speaking language of instruction & $\begin{array}{l}0=\text { Never; } 1=\text { Sometimes; } 2=\text { Most of time; } 3= \\
\text { All of the time }\end{array}$ & 1.05 & 1.07 & 1.20 & 0.99 \\
\hline Parents alive & $\begin{array}{l}0=\text { No parent alive; } 1=\text { One parent alive; } 2=\text { Both } \\
\text { parents alive }\end{array}$ & 1.51 & 0.75 & 1.69 & 0.57 \\
\hline Living with parents or relatives & $\begin{array}{l}0=\text { Living with a relative or another family; } 1= \\
\text { Living with one parent; } 2=\text { Living with both } \\
\text { parents }\end{array}$ & 1.32 & 0.75 & 1.42 & 0.74 \\
\hline Socioeconomic status & $\begin{array}{l}\text { Sum of the highest level of father and mother's } \\
\text { education (Each parent: } 0=\text { No school; } 1=\text { Primary } \\
\text { school; } 2=\text { Junior secondary school; } 3=\text { Senior } \\
\text { secondary school; } 4=\text { More than secondary school) } \\
\text { and number of } 16 \text { items at home (Each item: } 0= \\
\text { No; } 1=\text { Yes) }\end{array}$ & 11.11 & 4.82 & 11.61 & 4.75 \\
\hline Number of books at home & $0=0 ; 1=1-5 ; 2=5-10 ; 3=$ More than 10 & 0.87 & 1.07 & 0.82 & 1.04 \\
\hline Distance to school & $\begin{array}{l}0.5=0.0-0.5 \mathrm{~km} ; 1.0=0.6-1.0 \mathrm{~km} ; 1.5=1.1-1.5 \\
\mathrm{~km} ; 2.0=1.6-2.0 \mathrm{~km} ; 2.5=2.0-2.5 \mathrm{~km} ; 3.0= \\
2.5-3.0 \mathrm{~km} ; 3.5=\text { More than } 3.0 \mathrm{~km}\end{array}$ & 1.27 & 0.79 & 1.39 & 0.87 \\
\hline Household tasks & $\begin{array}{l}\text { Sum of the involvement of students in } 12 \\
\text { household activities (Each activity: } 0=\text { Never; } 1= \\
\text { Some days; } 2=\text { Most of days) }\end{array}$ & 13.40 & 6.71 & 16.14 & 4.21 \\
\hline Meals per week & $\begin{array}{l}\text { Total number of meals (breakfast, lunch, and } \\
\text { supper) taken by student per week (Each meal: } 0= \\
\text { Not at all; } 1=1-2 \text { days per week; } 2=3-4 \text { days per } \\
\text { week; } 3=\text { Everyday per week) }\end{array}$ & 4.78 & 2.75 & 5.60 & 2.65 \\
\hline Homework help at home & $\begin{array}{l}0=\text { Never; } 1=\text { Sometimes; } 2=\text { Most of time; } 3= \\
\text { All of the time }\end{array}$ & 1.22 & 1.05 & 1.18 & 1.03 \\
\hline Paying fees & $\begin{array}{l}\text { Fees of extra class, report card, term examination, } \\
\text { and school development (Each item: } 0=\text { Never; } 1= \\
\text { Sometimes; } 2=\text { Most of time; } 3=\text { All of the time) }\end{array}$ & 5.26 & 2.79 & 6.88 & 2.99 \\
\hline Parental support & $\begin{array}{l}\text { Sum of participating meeting and school activities, } \\
\text { and talking with teachers (Each item: } 0=\text { Never; } 1 \\
=\text { Sometimes; } 2=\text { Most of the time; } 3=\text { All of the } \\
\text { time) }\end{array}$ & 4.93 & 2.78 & 5.79 & 2.60 \\
\hline
\end{tabular}

Appendix C. Descriptive Statistics of School-Level Factors

\begin{tabular}{|c|c|c|c|c|c|}
\hline \multirow{2}{*}{ Variable name } & \multirow{2}{*}{ Scale } & \multicolumn{2}{|c|}{ Cohort 1} & \multicolumn{2}{|c|}{ Cohort 2} \\
\hline & & $M$ & $S D$ & $M$ & $S D$ \\
\hline Mean achievement & & 995.84 & 77.16 & 991.49 & 59.00 \\
\hline Mean socioeconomic status & & 11.12 & 1.44 & 11.62 & 1.79 \\
\hline Mean number of grade repetitions & & 1.00 & 0.20 & 0.88 & 0.15 \\
\hline Class size & & 95.94 & 43.03 & 73.13 & 36.72 \\
\hline School location & $0=$ Rural; $1=$ Semi-urban; $2=$ Urban & 0.24 & 0.43 & 0.18 & 0.38 \\
\hline School facilities & $\begin{array}{l}\text { Sum of } 6 \text { items: library, hall, staff room, } \\
\text { head teacher's room, playground, and } \\
\text { school garden (Each item: } 0=\text { No; } 1=\text { Yes) }\end{array}$ & 2.77 & 1.03 & 2.70 & 1.03 \\
\hline
\end{tabular}

